\title{
Effects of different anesthesia techniques on intraoperative blood loss in acetabular fractures undergoing the Modified Stoppa approach
}

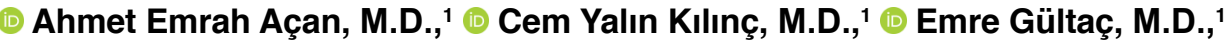

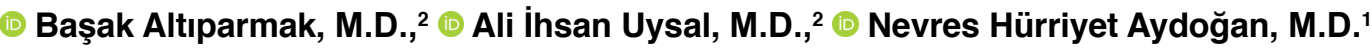

\begin{abstract}
${ }^{1}$ Department of Orthopedics and Traumatology, Muğla Sıtkı Koçman University Faculty of Medicine, Muğla-Turkey
${ }^{2}$ Department of Anesthesiology and Reanimation, Muğla Sıtkı Koçman University Faculty of Medicine, Muğla-Turkey
\end{abstract}

\begin{abstract}
BACKGROUND: This study aims to evaluate the effects of the anesthesia technique on the intraoperative blood loss in acetabular fracture patients undergoing the Modified Stoppa approach.

METHODS: We retrospectively identified 63 patients who underwent a Modified Stoppa approach for acetabular fracture from January 2014 to July 2018. A total of 20 patients were excluded from this study for the following reasons: bilateral acetabular fractures $(n=6)$, undergoing antiaggregant treatment $(n=3)$, incomplete anesthesia records $(n=3)$, emergency pelvic surgery due to hemodynamic instability $(n=5)$, splenic rupture $(n=2)$, and liver laceration $(n=1)$. The patients were divided into two groups as follows: patients undergoing general anesthesia (GA) $(n=22)$ and patients undergoing combined epidural-general anesthesia (CEGA) $(n=2 I)$. The main outcome measurements studied were the intraoperative blood loss and the need for intraoperative and/or postoperative blood transfusions.

RESULTS: No statistically significant differences were found between the groups concerning the age, gender, type of fracture, mechanism of injury, time from injury to surgery, Injury Severity Score, associated injuries, and comorbidities ( $p>0.05)$. The mean intraoperative blood losses were $717.27 \mathrm{ml}(300-1.600 \mathrm{ml})$ in the GA group and $473.81 \mathrm{ml}(150-1.020 \mathrm{ml})$ in the CEGA group ( $p<0.00 \mathrm{I})$. In the cases with only an isolated acetabular fracture, the intraoperative blood transfusion means were 2.43 units (I-5 units) in I4 patients in the GA group and I.27 units ( $I-4$ units) in I5 patients in the CEGA group $(\mathrm{p}<0.00 \mathrm{I})$.
\end{abstract}

CONCLUSION: Less intraoperative bleeding was seen in those patients undergoing CEGA when compared to those undergoing GA. This is a significant advantage for acetabular surgery, which has a long learning curve and a high risk of bleeding.

Keywords: Acetabular fracture; bleeding; blood loss; epidural anesthesia; Stoppa.

\section{INTRODUCTION}

General anesthesia (GA) is the most frequently used anesthesia method in major orthopedic surgeries. ${ }^{\left[{ }^{[]}\right.}$However, in studies related to hip and knee arthroplasty, hip fractures, and pelvic tumors, the use of epidural anesthesia has been reported to provide several advantages, such as a lower risk of deep vein thrombosis and pulmonary embolism, a decrease in intraoperative blood loss, better postoperative pain control, and a reduction in perioperative complications. ${ }^{[2-8]}$
Acetabular fractures are usually high-energy traumatic injuries. [9] When carrying out surgery to repair these fractures, a significant amount of bleeding may develop during the approach. Moreover, because these fractures are often accompanied by fractures in other regions, high intraoperative blood loss amounts may be seen. ${ }^{[10]}$ Unfortunately, an intraoperative and/ or postoperative blood transfusion involves risks and complications, such as an allergic reaction, transfusion of the wrong blood group, transfusion of infectious agents, and transfusionrelated down-modulation of the immune system. ${ }^{[1-14]}$

Cite this article as: Açan AE, Kılınç CY, Gültaç E, Altıparmak B, Uysal Aİ, Hürriyet Aydoğan N. Effects of different anesthesia techniques on intraoperative blood loss in acetabular fractures undergoing the Modified Stoppa approach. Ulus Travma Acil Cerrahi Derg 2020;26:445-452.

Address for correspondence: Ahmet Emrah Acan, M.D.

Muğla Sıtkı Koçman Üniversitesi Tıp Fakültesi, Ortopedi ve Travmatoloji Anabilim Dalı, Muğla, Turkey

Tel: +90252 - 2141326 E-mail: dremrahacan@hotmail.com

Ulus Travma Acil Cerrahi Derg 2020;26(3):445-452 DOI: 10.14744/tjtes.2019.09294 Submitted: 22.02.2019 Accepted: 09.08.2019 Online: I5.05.2020

Copyright 2020 Turkish Association of Trauma and Emergency Surgery 
Despite several studies in the current literature related to the Modified Stoppa technique and the associated blood losses, there is insufficient information about the relationship between the anesthetic technique and the amount of intraoperative bleeding. ${ }^{[10,15-22]}$ The present study aims to investigate whether or not there was a difference in the intraoperative blood loss between acetabular fracture cases undergoing GA and cases undergoing combined epidural-general anesthesia (CEGA) operated on using the Modified Stoppa technique.

\section{MATERIALS AND METHODS}

Approval for this study was granted by the Faculty ethics committee. A retrospective evaluation was conducted of patients aged over 18 years old with an acetabular fracture who underwent the Modified Stoppa technique at the Medical Faculty hospital between January 2014 to July 2018. All the medical records were reviewed for the demographic data, Injury Severity Score (ISS), mechanism of injury, number of associated fractures, number of associated medical comorbidities, time from injury to surgery, operation time, and amount of blood lost during the operation. The exclusion criteria were as follows: patients with bilateral acetabular fractures, a preoperative international normalized ratio (INR) value of $\geq 1.3$, receiving anticoagulant/antiaggregant treatment, a platelet count lower than $100.000 / \mathrm{mcL}$ or over $450.000 / \mathrm{mcL}$, incomplete anesthesia records, intraoperative iatrogenic major vascular injury, previous surgery with bleeding before orthopedic surgery, an indication for emergency surgery, intraoperative hemodynamic instability, and a known bleeding diathesis, such as chronic liver disease.

Anesthesia was administered to all patients by the same two anesthesiologists. In the operating room, standard monitoring was performed with the help of electrocardiography, invasive blood pressure measurements, pulse oximetry, and bi-spectral index monitoring (BIS). All the patients were hemodynamically stable before the operation. For induction of anesthesia, all the patients routinely received $2-3 \mathrm{mg} / \mathrm{kg}$ of propofol, I-2 mcg/ $\mathrm{kg}$ of fentanyl, and $0.6 \mathrm{mg} / \mathrm{kg}$ of rocuronium bromide until the BIS values decreased under 60 . The maintenance of anesthesia was provided with I-2\% sevoflurane in $40 \% \mathrm{O}_{2}+60 \% \mathrm{~N}_{2} \mathrm{O}$ mixture with targeting a $\mathrm{BIS}$ ratio between 40-60. In the CEGA group, after induction, the patients were placed in the lateral decubitus position, with the healthy extremity underneath, and an epidural catheter was placed in the L3-L4 interspace using the loss-of-resistance technique. In all the patients in the CEGA group, immediately after the surgical incision, the controlled administration of $9 \mathrm{ml}$ of $0.25 \%$ bupivacaine $+50 \mathrm{mcg}$ of fentanyl was applied from the epidural catheter. When there was a $>20 \%$ increase in the intraoperative parameters from the basal values, a dose of $4.5 \mathrm{ml}$ of $0.25 \%$ bupivacaine $+25 \mathrm{mcg}$ of fentanyl was administered from the epidural catheter in CEGA group and intravenous $0.5 \mathrm{mcg} \mathrm{kg}^{-1}$ fentanyl was administered as a bolus dose in GA group. When there was a $>20 \%$ reduction in the intraoperative parameters from the basal values, intravenous $5 \mathrm{mg}$ ephedrine was administered as a bolus dose in both groups. For postoperative pain control, the epidural catheter was used for 48 hours, and it was removed at the end of the $2^{\text {nd }}$ postoperative day.

Intraoperative blood loss during the Modified Stoppa intervention was recorded using data-linkage to surgical anesthesia records. The anesthesia team calculated intraoperative blood loss by evaluating the number of used small swabs and suction bottle contents. During the surgery, only small swabs were used, and these were collected and counted at the end of the procedure. According to previous literature, ${ }^{[23]}$ each saturated small swab was accepted as containing $60 \mathrm{~mL}$ of blood, and the amount of blood aspirated intraoperatively was calculated by subtracting the amount of saline used intraoperatively from the accumulated material in the suction bottle. The amount of intraoperative bleeding was calculated from these two values and recorded routinely by the anesthesia team. The operating time was accepted as the time from the start of the skin incision for the Modified Stoppa technique in the pelvic region to the time of skin closure.

An intraoperative transfusion of packed red blood cells was given to those patients with hemoglobin $(\mathrm{Hb})$ levels $<8 \mathrm{mg} / \mathrm{dL}$ and/or ongoing blood loss. A postoperative transfusion was given to the patients with $\mathrm{Hb}$ levels $<8 \mathrm{mg} / \mathrm{dL}$ and $\mathrm{Hb}$ levels $<9 \mathrm{mg} / \mathrm{dL}$ with signs or symptoms of anemia (i.e., dizziness, shortness of breath, tachypnea, or tachycardia). The intraoperative and postoperative transfused red blood cell numbers were also recorded.

\section{Statistical Analysis}

All the computational analyses were conducted using the $R$ software for statistical computing. The Welch's t-test was used to assess the differences between the patients in the two groups in terms of the age, ISS, operation time, and amount of intraoperative blood loss. The summary statistics of the compared values were presented as the mean \pm standard deviation. The correlations between the operation time and the amount of blood lost during the operation were calculated using the Pearson correlation coefficient. A p-value of $<0.05$ was considered to be statistically significant.

\section{RESULTS}

A total of 20 patients were excluded from this study: Six patients had bilateral acetabular fractures, three patients were taking antiaggregant medications, three patients had incomplete intraoperative anesthesia records, five patients were hemodynamically unstable and required emergency surgery, and two patients with splenic ruptures and one patient with a liver laceration were emergencies that were operated on by the general surgery team. After the implementation of the exclusion criteria, this study included a total of 43 patients 
(26 males and 17 females, aged 18-80 years old) who were operated on using the Modified Stoppa technique. The patients were separated into two groups as follows: a GA group $(n=22)$ and a CEGA group $(n=21)($ Table I). The mean age of the patients was 38.3 years old ( $18-70$ years) in the GA group and 40.1 years old (19-67 years) in the CEGA group. There were no statistically significant differences between the groups concerning the age, gender, type of fracture, mechanism of injury, ISS, associated injuries, and comorbidities ( $p>0.05)$ (Table I). The ISS means were I3.9 (9-34) in the GA group and 14.7 (10-37) in the CEGA group, with no statistically significant difference between the groups $(p>0.05)$.

All the patients were exposed to high-energy trauma. The mechanisms of trauma included being struck by a motor vehicle in 14 cases, a traffic accident within the vehicle in 19 cases, and a fall from a height in 10 cases (Table I). According to the Judet and Letournel classification, the fractures were as follows: I 4 anterior columns, eight transverse columns, II both columns, five anterior columns plus posterior hemitransverse, and five T-type fractures. ${ }^{[24]}$ Due to concomitant head trauma in three patients, thoracic injury in three patients, intra-abdominal pathology in two patients, and fractures in other regions in one patient, a total of nine patients were transferred from the emergency department to the intensive care unit (ICU) for close monitoring. After the clinical stabilization of these patients (mean: 5.6 days, range: $2-1$ I days), they were transferred to the orthopedics clinic. In eight patients in the GA group and six patients in the CEGA group, there were long bone fractures other than the patients in the pelvic region (Table I). All the patients were operated on by the same orthopedic surgeon using the Modified Stoppa technique at a mean of 7.I days (5-14 days) after the initial presentation. The means were 6.95 days (5-12 days) in the GA group and 7.24 days (5-14 days) in the CEGA group. When considering that the patients were clinically stable, the timing of the operation was planned semi-electively. When there was a concomitant fracture, the surgical intervention was conducted on the acetabular fracture first.

The mean preoperative $\mathrm{Hb}$ values were $12.3 \mathrm{~g} / \mathrm{dL}$ (10.5-17.1 $\mathrm{g} / \mathrm{dL})$ in the GA group and $11.9(10.2-16.7)$ in the CEGA group. The mean INR values were 0.9 I IU (0.82-I.I IU) in the GA group and $0.95 \mathrm{IU}(0.86-\mathrm{I} .15 \mathrm{IU})$ in the CEGA group.

Table I. Patient demographic data $(n=43)$

\begin{tabular}{|c|c|c|c|}
\hline & GA group $(n=22)$ & CEGA group $(n=2 I)$ & $\mathbf{p}$ \\
\hline Mean age (years) & 38.3 & 40.1 & $>0.5$ \\
\hline Male/female & $12 / 10$ & $15 / 6$ & $>0.5$ \\
\hline Mean Injury Severity Score & 13.9 & 14.7 & $>0.5$ \\
\hline Mean hemoglobin & 12.3 & 11.9 & $>0.5$ \\
\hline Mean international normalized ratio & 0.91 & 0.95 & $>0.5$ \\
\hline Mean platelet count & 233.500 & 256.300 & $>0.5$ \\
\hline Concomitant fracture & 8 & 6 & \\
\hline \multicolumn{4}{|l|}{ Comorbidities } \\
\hline Diabetes mellitus & 2 & 3 & \\
\hline Chronic obstructive pulmonary disease & 0 & I & \\
\hline Hypertension & 5 & 4 & \\
\hline Injury to surgery (days) & 6.95 & 7.24 & $>0.5$ \\
\hline Operating time (minutes) & 155.9 & 148.1 & $>0.5$ \\
\hline \multicolumn{4}{|l|}{ Mechanism of injury } \\
\hline Struck by motor vehicle & 6 & 8 & \\
\hline Traffic accident inside the vehicle & II & 8 & \\
\hline Fall from height & 5 & 5 & \\
\hline \multicolumn{4}{|l|}{ Fracture type ${ }^{*}$} \\
\hline Anterior column fracture & 9 & 5 & \\
\hline Both columns fracture & 4 & 7 & \\
\hline Transverse fracture & 5 & 3 & \\
\hline Anterior column plus hemitransverse & 2 & 3 & \\
\hline T-type fracture & 2 & 3 & \\
\hline
\end{tabular}

*Judet and Letournel classification. GA: General anesthesia; CEGA: Combined epidural-general anesthesia. 


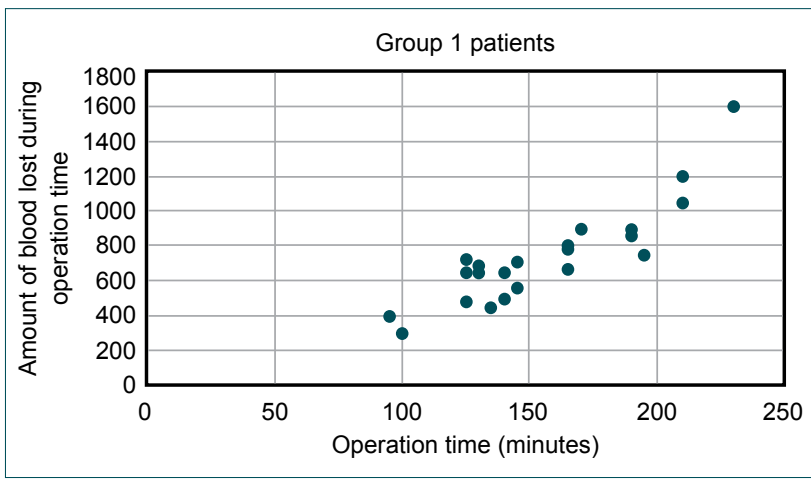

Figure 1. Representation of the amount of blood loss and operation time in group 1 patients.

The mean preoperative platelet counts were $233.500 / \mathrm{mcL}$ (121.000-376.000/mcL) in the GA group and $256.300 / \mathrm{mcL}$ (I $28.000-455.000 / \mathrm{mcL})$ in the CEGA group. No statistically significant differences were determined between the groups concerning the preoperative $\mathrm{Hb}$, INR, and platelet count values $(p>0.05)$. The mean operating time was 155.9 mins (95-230 mins) in the GA group and I 48.1 mins (90-240 mins) in the CEGA group, with no statistically significant difference between the groups $(p>0.05)$.

The mean amount of intraoperative blood loss was $717.27 \mathrm{~mL}$ $(300-1.600 \mathrm{~mL})$ in the GA group and $473.81 \mathrm{~mL}$ (150-1.020 $\mathrm{mL}$ ) in the CEGA group. The difference between the groups was determined to be statistically significant $(p<0.001)$ (Table 2 ). In both groups, a strong positive correlation was found between the operation time and the amount of blood lost; however, the correlation was stronger in the GA group ( $r=0.88$, $p<0.00 \mathrm{I})$ than in the CEGA group $(r=0.67, p<0.00 \mathrm{I})$ (Figs. I and 2). When the amount of blood lost was compared both within and between the groups according to the fracture type, the operation time was longer and the blood loss higher in those patients with T-type, transverse, and anterior column plus hemitransverse fractures when compared to the patients with the other types of fractures (anterior column and both columns) $(p<0.00 I)$. In the cases with no concomitant fractures and only an isolated acetabular fracture was treated using the Modified Stoppa approach, the intraoperative blood transfusion means were 2.43 units ( $(-5$ units) in 14 patients in the GA group and 1.27 units ( $\mathrm{I}-4$ units) in 15 patients in

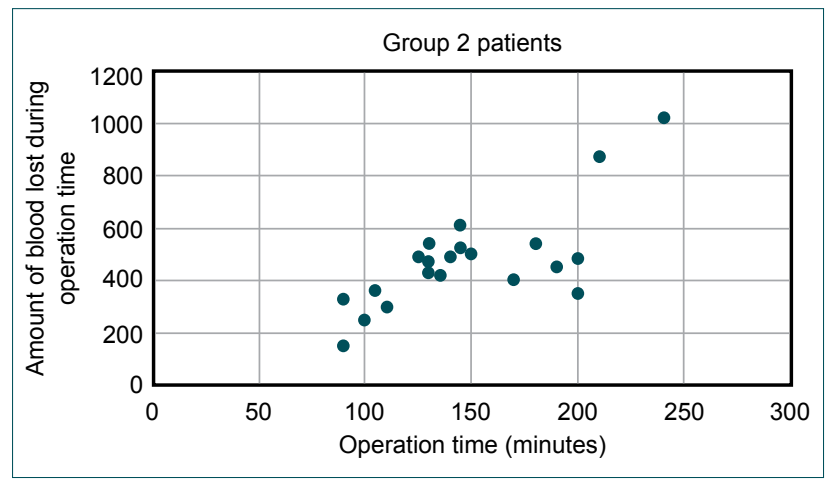

Figure 2. Representation of the amount of blood loss and operation time in group 2 patients.

the CEGA group. A statistically significant difference was observed between the two groups $(p<0.00 \mathrm{I})$ (Table 2$)$.

The postoperative blood transfusion means were 1.82 units ( $I-4$ units) in the GA group and $I .76$ units ( $0-4$ units) in the CEGA group. There was no statistically significant difference between the two groups ( $p>0.05)$. In the cases with no concomitant fractures and only an isolated acetabular fracture, the postoperative blood transfusion means were 1.64 units (I-3 units) in the GA group and I.53 units (I-3 units) in the CEGA group. No statistically significant difference was seen between the two groups concerning the postoperative blood transfusion amounts $(p>0.05)$.

When the time from operation to discharge was examined, the mean was 6.7 days (4-II days) in the GA group and 6.3 days (3-9 days) in the CEGA group, with no statistically significant difference between the groups $(p>0.05)$.

A mortality follow-up of the patients was conducted until the 90th postoperative day. In the GA group, one patient ( 80 years old) suffered a cardiac arrest on a postoperative day 37 and died. No statistically significant difference was found between the groups concerning the 90 -day mortality rate $(p>0.05)$.

\section{DISCUSSION}

GA remains the most preferred anesthesia method in major orthopedic surgeries. ${ }^{[1]}$ However, with increased technical

Table 2. Intraoperative bleeding and transfusion amounts

\begin{tabular}{|c|c|c|c|}
\hline & GA group & CEGA group & $\mathbf{p}$ \\
\hline \multirow[t]{2}{*}{ Intraoperative bleeding amount (mL) } & $717.27(300-1600)$ & $473.81(150-700)$ & $<0.001$ \\
\hline & $n=22$ & $n=21$ & \\
\hline Intraoperative blood transfusion in patients with & $2.43(1-5)$ & $1.27(1-4)$ & $<0.001$ \\
\hline an isolated acetabular fracture (units) ${ }^{*}$ & $n=14$ & $n=15$ & \\
\hline
\end{tabular}

*In cases with concomitant fractures, this could have changed the requirement for an intraoperative blood transfusion; therefore, only the isolated acetabular fractures were evaluated. GA: General anesthesia; CEGA: Combined epidural-general anesthesia. 
skills, the more frequent clinical use of catheters, and new technological developments, regional anesthesia has become more attractive to surgeons and anesthesiologists. ${ }^{[25,26]}$ There are many studies in the literature that have shown the superiority of epidural anesthesia over general anesthesia, although most of these studies have evaluated the results of total hip and knee arthroplasties. ${ }^{[3,6,7,14,25-28]}$ However, previous studies have reported that reduced intraoperative bleeding is related to the application of epidural anaesthesia. ${ }^{[1,4,5,29]} \mathrm{A}$ reduction in blood loss with the use of epidural anesthesia during major surgery was first reported by Moir ${ }^{[30]}$ in 1968. The author explained this reduction by the effects of the sympathetic blockade that develops with epidural anesthesia. The sympathetic blockade is well-known to cause a reduction in peripheral resistance, with a fall in the venous pressure, which results in reduced circulation in the pelvic vessels. ${ }^{[30]}$ However, to our knowledge, none of these studies evaluated the effects of regional anesthesia on bleeding in acetabular fracture surgery using the Modified Stoppa approach.

In the current literature, there are some studies that compare general anesthesia (GA) with epidural anesthesia and/or combined regional and general anesthesia (CEGA) concerning bleeding in orthopaedic surgeries. ${ }^{[1,4,5,31]}$ Strauss et al. ${ }^{[1]}$ and Dauphin et al. ${ }^{[4]}$ compared to GA and CEGA groups. Dauphin et al. ${ }^{[4]}$ operated on 37 hip arthroplasty patients using GA in 17 cases and CEGA in 20 cases. The bleeding values were found $1,259.2 \pm 366.0 \mathrm{~mL}$ in the GA group and $663.8 \pm 299.0$ $\mathrm{mL}$ in the CEGA group. The authors reported that the most possible reason for less intraoperative bleeding in the CEGA group was the sympathetic blockade, as described by Moir previously. In a retrospective study by Strauss et al., ${ }^{[1]}$ a total of I 38 posterior acetabular fracture patients were operated on using the Kocher-Langenbeck approach (64 with GA and 74 with CEGA). The patients were compared concerning the hospital length of stay, postoperative pain control, time to mobilization with physical therapy, and intraoperative blood loss. No differences were reported between the groups concerning the length of stay, pain score, or time to rehabilitation. Although not highly clinically significant, a statistically significant difference was determined in the intraoperative bleeding ( $458 \mathrm{~mL}$ in the CEGA group and $543 \mathrm{~mL}$ in the GA group). Similar to Dauphin et al., Strauss et al. ${ }^{\left[{ }^{[]}\right.}$reported sympathetic blockade as a possible reason for less blood loss in the epidural group. In another study, Freeman et al. ${ }^{[5]}$ evaluated the effects of anesthesia on the amount of bleeding in intrapelvic tumor surgeries, a total of 174 patients were retrospectively evaluated, with 102 patients administered hypotensive epidural anesthesia and 72 standard GA, to which a hemipelvectomy, sacrectomy, or hindquarter amputation was applied. The blood loss was $1.457 \mathrm{~mL}$ ( I. I I4-1.80 I mL) in the hypotensive epidural anesthesia group and 2.42I mL (I.877$2.965 \mathrm{~mL}$ ) in the GA group. The intraoperative mean arterial pressures were also lower in the epidural group throughout the operation. In this study, the authors suggested that less blood loss in the epidural group was not only related to the sympathetic blockade but also lower intraoperative mean arterial pressures (MAP). However, in the study of Strauss et al., ${ }^{[1]}$ intraoperative MAP changes were similar between the groups. The authors reported that the possible mechanism of less blood loss during their study was independent of hemodynamic changes. In our study, to provide a more standard sample group, we excluded the patients with unstable hemodynamic measurements. When there was a more than $20 \%$ increase in heart rate or MAP of the patients, the intraoperative hemodynamic management was performed with epidural administration of bupivacaine+fentanyl in CEGA group and intravenous administration of fentanyl in GA group. The intraoperative MAP measurements were similar between the groups. Consequently, we eliminated the effects of blood pressure on intraoperative bleeding.

Yadav et al., ${ }^{[1]}$ similar to Strauss et al., compared the effects of general anesthesia, regional anesthesia, and combined regional and general anesthesia on the perioperative outcomes of pelvi-acetabular fracture surgeries. They evaluated 59 patients retrospectively and reported intraoperative blood losses of $996.43 \pm 549.29 \mathrm{~mL}$ in the combined regional and general anesthesia group, $696.67 \pm 500.33 \mathrm{~mL}$ in the regional anesthesia group, and $870 \pm 516.79 \mathrm{~mL}$ in the general anesthesia group. Moreover, no significant differences were found between the three groups concerning the length of the hospital stay and duration of surgery, and they concluded that there was no specific significant advantage of this anesthetic technique on the observed perioperative complications in pelvi-acetabular fracture surgeries. ${ }^{[3]}$ However, no detailed information was provided about the surgical approach used, fracture type, how many surgeons performed the surgeries, and method for determining the intraoperative blood loss. In addition, the patient position and approach showed statistical significance among the groups. ${ }^{[3]}$ In the current study, GA or CEGA was administered while using the Modified Stoppa technique in acetabular fracture cases. Epidural anesthesia was not used alone. Because the positioning of a patient with an acetabular fracture for epidural anesthesia administration is a painful procedure, and it is almost impossible for a patient to tolerate this. By positioning the patient laterally after administering GA, the pain associated with the positioning can be overcome, and the placement of the epidural catheter is facilitated, with easier access to the epidural space. Another advantage of performing general anesthesia in both groups is that we presumably eliminated a probable effect of inhaled anesthetics on bleeding. All of the patients received sevoflurane for the maintenance of anesthesia by targeting the same BIS values. However, there were no data concerning the minimum alveolar concentration (MAC) values of sevoflurane overtime on anesthesia records of the patients.

In the current study, the intraoperative blood losses were $717.27 \mathrm{~mL}(300-1.600 \mathrm{~mL})$ in the 22 patients in the GA group and $473.81 \mathrm{~mL}(150-1.020 \mathrm{ml})$ in the 21 patients in the CEGA group. The difference between the two groups 
was statistically significant $(p<0.00 \mathrm{I})$. Strauss et al. concluded that a difference of approximately $100 \mathrm{~mL}$ between the GA and CEGA groups in the intraoperative bleeding was unlikely to be of clinical significance in contrast to reports in the literature suggesting that the use of supplemental epidural anesthesia in arthroplasty cases provided a reduction in intraoperative bleeding. ${ }^{[4,32]}$ However, in the present study, the mean difference between the groups was $234 \mathrm{~mL}$ and it should be accepted as clinically significant. ${ }^{[4]}$ The surgical approach in Strauss et al.'s ${ }^{[1]}$ study was using the Kocher-Langenbeck incision, which is an extra-pelvic approach, whereas in the present study was Modified Stoppa approach, which is an intrapelvic approach. Another study related to intrapelvic approach by Freeman et al., ${ }^{[5]}$ mean intraoperative bleeding difference between the hypotensive epidural anesthesia and GA groups in surgeries undergoing intrapelvic approach was $964 \mathrm{~mL}$ with clinical significance. However, in that study, intrapelvic tumors were evaluated, not fractures, and the GA was compared to hypotensive epidural anesthesia. On the one hand, this may suggest that in intrapelvic interventions, such as the Modified Stoppa approach, the pelvic vascularity is higher when compared to cases undergoing an extrapelvic approach, such as the Kocher-Langenbeck. Thus, there is a higher risk of bleeding. On the other hand, the use of CEGA when there is a higher potential for bleeding, such as in the intrapelvic approach, has been shown to be advantageous concerning the amount of intraoperative bleeding.

In the Strauss et al.'s ${ }^{[1]}$ study, a cell saver machine was used when calculating the intraoperative bleeding amount, and the anesthesiologists estimated the blood loss based on the machine's recordings. In a previously published arthroplasty series by Freeman et al., ${ }^{[5]}$ the blood loss was determined indirectly using a formula, including the preoperative and postoperative $\mathrm{Hb}$ levels and the number of units of red blood cells transfused ${ }^{[33]}$ It has been advocated that with this method, surgeon or anesthesiologist bias could be avoided, and the amount of blood on the drapes, gowns, and the operating room floor could be overlooked with other methods. ${ }^{[5]}$ In the present study, the amount of intraoperative bleeding was determined from the small swab count and suction bottle contents values that were recorded by the anesthesia team. With this method, and with the Modified Stoppa approach being performed in the supine position, it is believed that the amount of blood on the drapes, gowns, and operating room floor was not of a degree to affect the measurement. In addition, because the pelvic surgery was applied first to those patients with a concomitant fracture, only the amount of intraoperative blood lost when using the Modified Stoppa approach could be calculated.

When the current literature is examined, it can be seen that many studies have provided mean operating times. ${ }^{[1,4,5,10,15-}$ 22,28,29] However, to our knowledge, there is not any study in the literature that showed a direct relationship between an increased operating time and an increased blood loss. In the present study, the operating times of the patients that were given GA and CEGA were 156 mins and 148 mins, respectively, with no statistically significant difference between the groups $(p=0.544)$. Again, in both groups, the operating times of the patients with T-type, both column, and anterior column plus hemitransverse fractures were longer than the operating times of the patients with the other types of fractures, and the amount of bleeding was higher $(p<0.001)$. Thus, it can be said that when the fracture type is more complicated, the operating time is prolonged, and the amount of blood loss is increased.

Controlled hypotension, autologous blood transfusion, intra-operative blood salvage, and the use of erythropoietin and antifibrinolytic agents are other described blood conserving techniques to reduce blood loss and post-operative transfusion rate, similar to the aim of this study. ${ }^{[34,35]}$ The antifibrinolytics include aprotinin, epsilon-aminocaproic acid and tranexamic acid (TXA). Among them, TXA has attracted the most attention. However, its use is controversial in orthopaedic trauma patients due to its theoretical risk of increased thromboembolic complications. However, Gausden et al. ${ }^{[6]}$ reported a systematic review and meta-analysis concluded that tranexamic acid reduced the risk of blood transfusion, reduces perioperative blood loss, and had no significant effect on the risk of symptomatic thromboembolic events. Sukeik et al. ${ }^{[37]}$ and Alshryda et al. ${ }^{[38]}$ reported systematic review and meta-analysis of the use of TXA in total knee replacement and total hip replacement respectively. They reported reduced blood loss using $104 \mathrm{~mL}$ and $591 \mathrm{~mL}$ in total hip replacement and total knee replacement, respectively. Additionally, no increased risk of deep vein thrombosis and pulmonary embolism was reported due to TXA use both in total knee and hip replacement surgeries. In this study, we did not evaluate the effects of TXA on blood loss in acetabular fracture patients undergoing the Modified Stoppa approach. However, it would not be wrong to foresee that TXA would potentiate the reduction in the blood loss effects of CEGA.

A major limitation of this study was that this study was retrospective, and therefore prone to various forms of bias (selection bias and recall bias). Besides, retrospective evaluation of the calculation of the intraoperative blood loss may lead to a question mark about the reliability of this study. However, in our clinic, anesthesia team determines the intraoperative blood loss by evaluating the number of used saturated of small swabs and suction bottle contents and records the amount of intraoperative blood loss to the patient anesthesia form as a daily routine practice. In addition, the number of patients was relatively low. In a broader patient group, potential differences could be revealed according to the fracture type. A further limitation of this study was that the pain scores were not recorded. Thus, pain control could not be evaluated. If there had been such an evaluation, the effects of the epidural analgesia during the postoperative period concerning the pain and reducing the opioid-induced side-effects 
(thereby providing earlier postoperative rehabilitation and shortening the postoperative length of the hospital stay), as have been reported in total hip and knee arthroplasty cases in the literature, might have been similar to those in the acetabular fractures undergoing Modified Stoppa surgery. ${ }^{[39,40]}$ However, Strauss et al. ${ }^{[1]}$ found no difference between the patients administered CEGA or GA for acetabular posterior wall fractures about the length of stay, postoperative pain scores, or time to rehabilitation, but they stated that larger patient populations were required. As mentioned before, we had no date concerning the MAC values of sevoflurane overtime on anesthesia records of the patients. Unfortunately, we could not assess the effects of MAC values on intraoperative bleeding in this study.

The major strengths of this study were the homogeneity between the groups, and that the surgeries were carried out by the same surgeon in all the cases. In the study by Strauss et al., $^{[1]}$ the operation was performed by one of 10 faculty orthopedic traumatologists, and the type of anesthesia used was determined by one of 18 faculty anesthesiologists for each procedure. Therefore, the anesthesiologists may have exhibited a selection bias in preferring the CEGA over GA for the patients at a higher risk of intraoperative blood loss and decreased postoperative mobility. In the study by Freeman et al., ${ }^{[5]}$ the anesthetic technique used was primarily determined by the anesthesiologist, and it lacked randomization. Similarly, in the present study, the type of anesthesia used was determined by the same two anesthesia specialists, who may have also exhibited selection bias.

\section{Conclusion}

In the acetabular fracture cases in which the Modified Stoppa technique was used, less intraoperative bleeding was seen in the patients administered CEGA when compared to the patients administered GA. This is a significant advantage for acetabular surgeries, which has a long learning curve and a high risk of bleeding. In further prospective, randomized, controlled trials with larger patient populations, higher benefits can be obtained by not concentrating on the amount of bleeding, but by conducting a more comprehensive evaluation concerning the other benefits of the technique and its perioperative complications.

Ethics Committee Approval: Approved by the local ethics committee.

Peer-review: Internally peer-reviewed.

Authorship Contributions: Concept: A.E.A, C.Y.K., B.A.; Design: A.E.A, C.Y.K., B.A.; Supervision: C.Y.K., B.A.; Materials: B.A., A.I.U.; Data: B.A., A.I.U.; Analysis: A.E.A., B.A.; Literature search: A.E.A., E.G., B.A.; Writing: A.E.A., B.A.; Critical revision: N.H.A.

Conflict of Interest: None declared.

Financial Disclosure: The authors declared that this study has received no financial support.

\section{REFERENCES}

1. Strauss JE, O'Toole RV, Pollak AN. Does supplemental epidural anesthesia improve outcomes of acetabular fracture surgery?. J Orthop Trauma 2012;26:67-72. [CrossRef]

2. Davis FM, Laurenson VG, Gillespie WJ, Wells JE, Foate J, Newman E. Deep vein thrombosis after total hip replacement. A comparison between spinal and general anaesthesia. J Bone Joint Surg Br 1989;71:181-5.

3. Urwin SC, Parker MJ, Griffiths R. General versus regional anaesthesia for hip fracture surgery: a meta-analysis of randomized trials. $\mathrm{Br} \mathrm{J}$ Anaestg 2000;84:450-5. [CrossRef]

4. Dauphin A, Raymer KE, Stanton EB, Fuller HD. Comparison of general anesthesia with and without lumbar epidural for total hip arthroplasty: effects of epidural block on hip arthroplasty. J Clin Anesth 1997;9:2003. [CrossRef]

5. Freeman AK, Thorne CJ, Gaston CL, Shellard R, Neal T, Parry MC, et al. Hypotensive Epidural Anesthesia Reduces Blood Loss in Pelvic and Sacral Bone Tumor Resections. Clin Orthop Relat Res 2017;475:634-40.

6. Choi PT, Bhandari M, Scott J, Douketis J. Epidural analgesia for pain relief following hip or knee replacement. Cochrane Database Syst Rev 2003;3:CD003071. [CrossRef]

7. Kita T, Maki N, Song YS, Arai F, Nakai T. Caudal epidural anesthesia administered intraoperatively provides for effective postoperative analgesia after total hip arthroplasty. J Clin Anesth 2007;19:204-8. [CrossRef]

8. Pellegrini VD Jr, Sharrock NE, Paiement GD, Morris R, Warwick DJ. Venous thromboembolic disease after total hip and knee arthroplasty: current perspectives in a regulated environment. Instr Course Lect 2008;57:637-61.

9. Letournel E, Judet R. Fractures of the acetabulum. Berlin, Heidelberg: Springer; 1993. [CrossRef]

10. Hirvensalo E, Lindahl J, Kiljunen V. Modified and new approaches for pelvic and acetabular surgery. Injury 2007;38:431-41. [CrossRef]

11. Klein HG. Allogeneic transfusion risks in the surgical patient. Am J Surg 1995;170:21S-6S. [CrossRef]

12. Transfusion alert: use of autologous blood. National Heart, Lung, and Blood Institute Expert Panel on the use of Autologous Blood. Transfusion 1995;35:703-11. [CrossRef]

13. Dodd RY. Current estimates of transfusion safety worldwide. Dev Biol (Basel) 2005;120:3-10.

14. Bierbaum BE, Callaghan JJ, Galante JO, Rubash HE, Tooms RE, Welch RB. An analysis of blood management in patients having a total hip or knee arthroplasty. J Bone Joint Surg Am 1999;81:2-10. [CrossRef]

15. Isaacson MJ, Taylor BC, French BG, Poka A. Treatment of acetabulum fractures through the modified Stoppa approach: strategies and outcomes. Clin Orthop Relat Res 2014;472:3345-52. [CrossRef]

16. Elmadağ M, Güzel Y, Acar MA, Uzer G, Arazi M. The Stoppa approach versus the ilioinguinal approach for anterior acetabular fractures: a case control study assessing blood loss complications and function outcomes. Orthop Traumatol Surg Res 2014;100:675-80. [CrossRef]

17. Sagi HC, Afsari A, Dziadosz D. The anterior intra-pelvic (modified rivesstoppa) approach for fixation of acetabular fractures. J Orthop Trauma 2010;24:263-70. [CrossRef]

18. Liu Y, Yang H, Li X, Yang SH, Lin JH. Newly modified Stoppa approach for acetabular fractures. Int Orthop 2013;37:1347-53. [CrossRef]

19. Ponsen KJ, Joosse P, Schigt A, Goslings JC, Luitse JS. Internal fracture fixation using the Stoppa approach in pelvic ring and acetabular fractures: technical aspects and operative results. J Trauma 2006;61:662-7. [CrossRef]

20. Bastian JD, Tannast M, Siebenrock KA, Keel MJ. Mid-term results in re- 
lation to age and analysis of predictive factors after fixation of acetabular fractures using the modified Stoppa approach. Injury 2013;44:1793-8.

21. Andersen RC, O'Toole RV, Nascone JW, Sciadini MF, Frisch HM, Turen CW. Modified stoppa approach for acetabular fractures with anterior and posterior column displacement: quantification of radiographic reduction and analysis of interobserver variability. J Orthop Trauma 2010;24:271-8.

22. Ma K, Luan F, Wang X, Ao Y, Liang Y, Fang Y, et al. Randomized, controlled trial of the modified Stoppa versus the ilioinguinal approach for acetabular fractures. Orthopedics 2013;36:e1307-15. [CrossRef]

23. Bose P, Regan F, Paterson-Brown S. Improving the accuracy of estimated blood loss at obstetric haemorrhage using clinical reconstructions. BJOG 2006;113:919-24. [CrossRef]

24. Letournel E. Acetabulum fractures: classification and management. Clin Orthop Relat Res 1980;151:81-106. [CrossRef]

25. Chelly JE, Greger J, Gebhard R, Coupe K, Clyburn TA, Buckle R, et al. Continuous femoral blocks improve recovery and outcome of patients undergoing total knee arthroplasty.J Arthroplasty 2001;16:436-45. [CrossRef]

26. Fischer HB, Simanski CJ, Sharp C, Bonnet F, Camu F, Neugebauer EA, et al; PROSPECT Working Group. A procedure-specific systematic review and consensus recommendations for postoperative analgesia following total knee arthroplasty. Anaesthesia 2008;63:1105-23. [CrossRef]

27. Borghi B, Casati A, Iuorio S, Celleno D, Michael M, Serafini PL, et al. Effect of different anesthesia techniques on red blood cell endogenous recovery in hip arthroplasty. J Clin Anesth 2005;17:96-101. [CrossRef]

28. Zhu M, Chen JY, Tan YR, Yew AK, Chong HC, Chia SL, et al. Effects of anesthetic technique on blood loss and complications after simultaneous bilateral total knee arthroplasty. Arch Orthop Trauma Surg 2015;135:565-71. [CrossRef]

29. Eroglu A, Uzunlar H, Erciyes N. Comparison of hypotensive epidural anesthesia and hypotensive total intravenous anesthesia on intraoperative blood loss during total hip replacement. J Clin Anesth 2005;17:420-5.

30. Moir DD. Blood loss during major vaginal surgery. A statistical study of the influence of general anaesthesia and epidural analgesia. Br J Anaesth
1968;40:233-40. [CrossRef]

31. Yadav N, Ahmad SR, Saini N, Gupta B, Sawhney C, Garg R, et al. Effect of anaesthesia on the perioperative outcomes of pelvi-acetabular fracture surgeries in the apex trauma centre of a developing country-a retrospective analysis. Burns Trauma 2015;3:10. [CrossRef]

32. Moonen AF, Neal TD, Pilot P. Peri-operative blood management in elective orthopaedic surgery. A critical review of the literature. Injury 2006;37:S11-6. [CrossRef]

33. Guay J. Postoperative pain significantly influences postoperative blood loss in patients undergoing total knee replacement. Pain Med 2006;7:476-82.

34. Cardone D, Klein AA. Perioperative blood conservation. Eur J Anaesthesiol 2009;26:722-9. [CrossRef]

35. Rajesparan K, Biant LC, Ahmad M, Field RE. The effect of an intravenous bolus of tranexamic acid on blood loss in total hip replacement. J Bone Joint Surg Br 2009;91:776-83. [CrossRef]

36. Gausden EB, Qudsi R, Boone MD, O'Gara B, Ruzbarsky JJ, Lorich DG. Tranexamic Acid in Orthopaedic Trauma Surgery: A Meta-Analysis. J Orthop Trauma 2017;31:513-9. [CrossRef]

37. Sukeik M, Alshryda S, Haddad FS, Mason JM. Systematic review and meta-analysis of the use of tranexamic acid in total hip replacement. J Bone Joint Surg Br 2011;93:39-46. [CrossRef]

38. Alshryda S, Sarda P, Sukeik M, Nargol A, Blenkinsopp J, Mason JM. Tranexamic acid in total knee replacement: a systematic review and metaanalysis. J Bone Joint Surg Br 2011;93:1577-85. [CrossRef]

39. Singelyn FJ, Deyaert M, Joris D, Pendeville E, Gouverneur JM. Effects of intravenous patient-controlled analgesia with morphine, continuous epidural analgesia, and continuous three-in-one block on postoperative pain and knee rehabilitation after unilateral total knee arthroplasty. Anesth Analg 1998;87:88-92. [CrossRef]

40. Peters CL, Shirley B, Erickson J. The effect of a new multimodal perioperative anesthetic regimen on postoperative pain, side effects, rehabilitation, and length of hospital stay after total joint arthroplasty. J Arthroplasty 2006;21:132-8. [CrossRef]

\section{ORIJIINAL ÇALIŞMA - ÖZET}

\section{Modifiye Stoppa yaklaşımı ile ameliyat edilen asetabulum kırıklarında farklı anestezi tekniklerinin intraoperatif kan kaybı üzerine etkisi \\ Dr. Ahmet Emrah Açan, ${ }^{1}$ Dr. Cem Yalın Kılınç, ${ }^{1}$ Dr. Emre Gültaç, ${ }^{1}$ Dr. Başak Altıparmak, ${ }^{2}$ Dr. Ali İhsan Uysal, ${ }^{2}$ Dr. Nevres Hürriyet Aydoğan ${ }^{1}$}

${ }^{1}$ Muğla Sıtkı Koçman Üniversitesi Tıp Fakültesi, Ortopedi ve Travmatoloji Anabilim Dalı, Muğla ${ }^{2}$ Muğla Sıtkı Koçman Üniversitesi Tıp Fakültesi, Anestezi ve Reanimasyon Anabilim Dalı, Muğla

AMAÇ: Asetabulum kırı̆ı̆ı nedeniyle Modifiye Stoppa yaklaşımı ile ameliyat edilen hastalardaki intraoperatif kanama miktarına, anestezi tekniğinin etkisini değerlendirmektir.

GEREÇ VE YÖNTEM: Ocak 2014 ve Temmuz 2018 tarihleri arasında asetabulum kırığı nedeniyle Modifiye Stoppa yaklaşımı ile ameliyat edilen 63 hasta geriye dönük olarak değerlendirildi. İki taraflı asetabulum kırığı $(n=6)$, antiagregan tedavisi $(n=3)$, anestezi kayıtlarında eksiklik $(n=3)$, hemodinamik instabilite nedeniyle acil pelvik cerrahi geçirmiş $(n=5)$, dalak yırtığı $(n=2)$ ve karaciğer yırtığı $(n=1)$ olan, toplam 20 hasta çalışmadan dışlandı. Hastalar genel anestezi yapılanlar (GA) $(n=22)$ ve kombine epidural-genel anestezi yapılanlar (CEGA) $(n=2 I)$ olmak üzere iki gruba ayrıldı. İntraoperatif kanama miktarı ve intraoperatif ve/veya ameliyat sonrası kan transfüzyon ihtiyacı, değerlendirilen ana ölçüm parametreleriydi.

BULGULAR: Gruplar arasında yaş, cinsiyet, kırık tipi, yaralanma mekanizması, yaralanma ile cerrahi arasındaki süre, yaralanma şiddet skoru, eşlik eden yaralanmalar ve komorbiditeler açısından istatistiksel anlamlı fark yoktu ( $p>0.05)$. Ortalama intraoperatif kanama miktarı GA grubunda $717.27 \mathrm{ml}(300-1.600 \mathrm{ml})$ ve CEGA grubunda $473.8 \mathrm{I} \mathrm{ml}(\mid 50-1.020 \mathrm{ml})$ bulundu $(p<0.00 \mathrm{I})$. İzole asetabulum kırğı olan olgularda ise, intraoperatif kan transfüzyon ortalaması, GA grubundaki I 4 hastada 2.43 ünite (I-5 ünite) ve CEGA grubundaki I 5 hastada I.27 ünite (I-4 ünite) bulundu $(\mathrm{p}<0.00 \mathrm{I})$.

TARTIŞMA: CEGA yapılan hastalarda, GA yapılan hastalara göre daha az intraoperatif kanama görüldü. Bu, uzun öğrenme eğrisi ve yüksek kanama riski olan asetabulum cerrahi için önemli bir avantajdır.

Anahtar sözcükler: Asetabulum kırı̆ı̆; epidural anestezi; kan kaybı; kanama; Stoppa.

Ulus Travma Acil Cerrahi Derg 2020;26(3):445-452 doi: 10.14744/tjtes.2019.09294 